\title{
Meningkatkan Kemampuan Mengenal Huruf Vokal Anak Melalui Permainan Gardu Kasur
}

\author{
Muthia Arya Putri \\ Pendidikan Profesi Guru Pasca Sarjana Universitas Negeri Padang \\ e-mail : muthiaaryap@gmail.com
}

\begin{abstract}
Abstrak
Penelitian ini bertujuan untuk mendeskripsikan proses dan hasil belajar melalui kegiatan bermain gardu kasur untuk meningkatkan kemampuan mengenal huruf vokal pada anak usia 5-6 tahun. Penelitian ini dilakukan di TK Villa Beta Padang. Metode yang digunakan adalah Penelitian Tindakan Kelas. Prosedur penelitian terdiri dari: perencanaan, tindakan dan observasi, refleksi. Teknik pengumpulan data dilakukan melalui tes, observasi, dan dokumentasi. Teknik analisis data yang digunakan dalam penelitian ini adalah analisis data kualitatif dan kuantitatif. Pra tindakan dilakukan untuk menentukan persentase kemampuan mengenal huruf vokal sebesar $51.07 \%$, meningkat menjadi63.39\% setelah siklus pertama, dan meningkat menjadi $84.82 \%$ setelah siklus kedua. Peningkatan $84.82 \%$ pada siklus kedua membuktikan bahwa kegiatan bermain gardu kasur dapat meningkatkan kemampuan mengenal huruf vokal anak usia dini. Kemampuan mengenal huruf dapat dikembangkan melalui kegiatan bermain gardu kasur, di mana dapat melatih daya ingat anak, dapat melatih kemampuan mengenal bentuk huruf dan kemampuan memecahkan masalah.
\end{abstract}

Kata Kunci: Gardu Kasur, Kemampuan Mengenal Huruf

\section{Abstract}

This study aims to describe the process and learning outcomes through the activity of playing mattress substations to improve the ability to recognize vowels in children aged 5-6 years. This research was conducted at TK Villa Beta Padang. The method used is Classroom Action Research. The research procedure consists of: planning, action and observation, reflection. Data collection techniques were carried out through tests, observations, and documentation. The data analysis technique used in this research is qualitative and quantitative data analysis. Pre-action was carried out to determine the percentage of ability to recognize vowels by $51.07 \%$, increasing to $63.39 \%$ after the first cycle, and increasing to $84.82 \%$ after the second cycle. An increase of $84.82 \%$ in the second cycle proves that playing the mattress substation can improve the ability to recognize vowels in early childhood. The ability to recognize letters can be developed through mattress substation playing activities, which can train children's memory, can train the ability to recognize letter shapes and problem solving skills.

Keywords: Gardu Kasur, Ability to Recognize Letters 


\section{PENDAHULUAN}

Pendidikan Anak Usia Dini (PAUD) merupakan suatu upaya yang ditujukan kepada anak usia dini yang dilakukan melalui pemberian ragsangan pendidikan untuk membantu pertumbuhan dan perkembangannya agar memiliki kesiapan dalam memasuki pendidika lebih lanjut. Pendidikan usia dini ini sangat penting dilakukan, karena pendidikan usia dini merupakan dasar dalam pembentukan kepribadian manusia. Sehingga pendidikan anak usia dini harus dirancang sesuai dengan kebutuhan anak agar dapat mengembangkan berbagai aspek perkembangan baik aspek agama dan moral, aspek kognitif, aspek bahasa, aspek sosialemosional, serta aspek fisik motorik.

Stimulasi yang diberikan kepada anak haruslah dapat mengembangkan aspek-aspek perkembangannya, salah satunya yaitu stimulasi bermain. Dunia anak usia dini adalah dunia bermain, setiap hari adalah bermain. Pada saat anak-anak bermain, mereka merasa senang dan bahagia. Oleh karena itu, untuk mengembangkan aspek-aspek perkembangan anak, kegiatan bermain tersebut harus diberikan pembelajaran-pembelajaran. Sehingga saat mereka bermain, tanpa mereka sadari mereka telah belajar. Hal tersebut telah dijelaskan oleh Mayke dalam bukunya bahwa belajar dengan bermain memberi kesempatan kepada anak untuk memanipulasi, mengulang, menemukan sendiri, bereksplorasi, mempraktikkan dan mendapat bermacam-macam konsep serta pengertian yang tidak terhitung banyaknya(Triharso Agung, 2013).

Bermain juga merupakan kegiatan yang sangat disenangi dan sangat menyenangkan bagi anak, setiap hari mereka melakukan aktivitas bermain. Bermain adalah keseluruhan aktivitas yang dilakukan oleh seseorang individu yang sifatnya menyenangkan, menggembirakan, dan menimbulkan kenikmatan yang berfungsi untuk membantu individu mencapai perkembangan yang utuh, baik fisik, intelektual, sosial, moral dan emosional(Purnama Sigit, 2019)

Berdasarkan hasil observasi di TK Villa Beta Padang, terlihat perkembangan mengenal huruf anak masih belum berkembang sesuai dengan yang diharapkan. Anak belum mampu menyebutkan huruf yang diperlihatkan terbukti anak masih berfikir lama ketika menyebutkan hurufnya. Oleh karena itu, kemampuan mengenal huruf anak perlu dikembangkan.

Guru dapat menyesuaikan tema pembelajaran kedalam permainan ini. bermain gardu kasur merupakan permainan yang mudah dipahami, mudah dilakukan dan mengandung pembelajaran yang dapat menstimulasi kemampuan mengenal huruf anak. Kurang bervariasi nya kegiatan di TK Villa beta disebabkan oleh guru kurang berani menggunakan media media baru pada anak serta guru belum memiliki pengetahuan mengenai media yang kreatif untuk anak usia dini.

Berdasarkan fenomena di atas, penulis menemukan strategi yang digunakan dalam bermain sangat bervariasi. Strategi tersebut dipakai salah satunya sebagai daya tarik anak dan pendalaman tujuan dari suatu permainan lempar dadu geometri. Hal ini penulis ambil karna penulis tahu betul pembelajaran anak itu bersifat " belajar seraya bermain" maksudnya dalam kegiatan bermain ada makna pembelajarannya. 
Chugeni (2009:56) menyatakan permainan kata yang menggunakan media di tujukan untuk anak yang sudah dapat mengeja kata sebagai latihan membaca. Bermain membutuhkan alat permainan yang dapat memberikan suasana bermain anak lebih menyenangkan. Penulis memilih bermain gardu kasur sebagai pengantar pembelajaran membaca awal anak usia dini.

\section{METODE}

Metode yang digunakan dalam penelitian ini adalah penelitian tindakan kelas Penelitian tindakan merupakan salah satu cara yang strategis bagi pendidik untuk meningkatkan dan atau memperbaki layanan pendidikan dalam konteks pembelajaran di kelas. Action Research adalah penelitian yang bersifat partisipatif dan kolaboratif, karena melibatkan orang-orang yang ada dilingkungannya dan hasilnya dapat dinikmati bersama. Hal ini menjelaskan bahwa penelitian tindakan bertujuan untuk menyelesaikan masalah yang ditemui sehari-hari dalam konteks pembelajaran di kelas (handini Myrnawati Crie, 2012).

Kriteria keberhasilan tindakan dalam penelitian ini mengacu pada kriteria yang ditetapkan oleh Mills, yang menyatakan bahwa penelitian tindakan memiliki target persentase menjadi $71 \%$ setelah melakukan tindakan pada subjek penelitian. Artinya, penelitian ini dikatakan berhasil jika $71 \%$ dari jumlah anak di kelas sudah mencapai standar yang telah ditetapkan oleh kolaborator yaitu $75 \%$ dengan mempertimbangkan situasi dan kondisi sekolah.

Penelitian ini melibatkan 10 orang anak berusia 5-6 tahun di TK Villa Beta. Bermain gardu kasur dimulai dengan memperkenalkan huruf vkal terlebih dahulu, anak diperkenalkan dengan macam macam huruf vokal. Keberhasilan penelitian diukur melalui indikator perkembangan mengenal huruf vokal anak yang pengambilan datanya melalui observasi oleh peneliti dan kolaborator.

Tabel 1. Kisi-kisi Instrumen

\begin{tabular}{|c|c|l|l|}
\hline Aspek & KD & \multicolumn{1}{|c|}{ Indikator } & \multicolumn{1}{|c|}{ Tujuan } \\
\hline Bahasa & $\begin{array}{l}3.12- \\
4.12\end{array}$ & $\begin{array}{l}\text { (1) memilih bentuk } \\
\text { bentuk simbol }\end{array}$ & $\begin{array}{l}\text { Anak mampu memilih } \\
\text { huruf vokal sesuai sub sub } \\
\text { tema }\end{array}$ \\
\cline { 3 - 4 } & & $\begin{array}{l}\text { (2) mampu } \\
\text { mengidentifikasi } \\
\text { suara huruf awal }\end{array}$ & $\begin{array}{l}\text { Anak } \\
\text { mengidentifikasi kata yang } \\
\text { berawalan huruf vokal } \\
\text { sesuai sub subtema }\end{array}$ \\
\cline { 3 - 4 } & $\begin{array}{l}\text { (3) mampu } \\
\text { mengidentifikasi } \\
\text { lambang lambang } \\
\text { huruf }\end{array}$ & $\begin{array}{l}\text { Anak } \\
\text { mengidentifikasi huruf } \\
\text { vokal yang ada pada kata } \\
\text { sesuai sub subtema }\end{array}$ \\
\hline
\end{tabular}

\section{HASIL PEMBAHASAN}

Penelitian tindakan ini terfokus pada peningkatan kemampuan mengenal huruf siswa TK Villa Beta usia 5-6 tahun dengan aspek bahasa. Indikator pertama Anak mampu memilih huruf vokal sesuai sub sub tema, indikator kedua: 
Anak mampu mengidentifikasi kata yang berawalan huruf vokal sesuai sub subtema, dan indikator ketiga: Anak mampu mengidentifikasi huruf vokal yang ada pada kata sesuai sub subtema.

Hasil tindakan kegiatan bermain gardu kasur meningkatkan kemampuan mengenal huruf vokal anak, antara lain adalah : Kesepakatan antara peneliti dan kolaborator dimana persentase rata-rata kriteria keberhasilan yang ditetapkan sebesar $75 \%$, maka penelitian yang dilakukan di TK Villa Beta dinyatakan berhasil karena anak telah mengalami peningkatan perolehan skor minimal $75 \%$. Peningkatan keberhasilan penelitian di awal pra-tindakan dilakukan untuk menentuan persentase kemampuan mengenal huruf vokal anak sebesar $51.07 \%$, meningkat menjadi $63.39 \%$ setelah siklus pertama, dan meningkat menjadi $84.82 \%$ setelah siklus kedua.

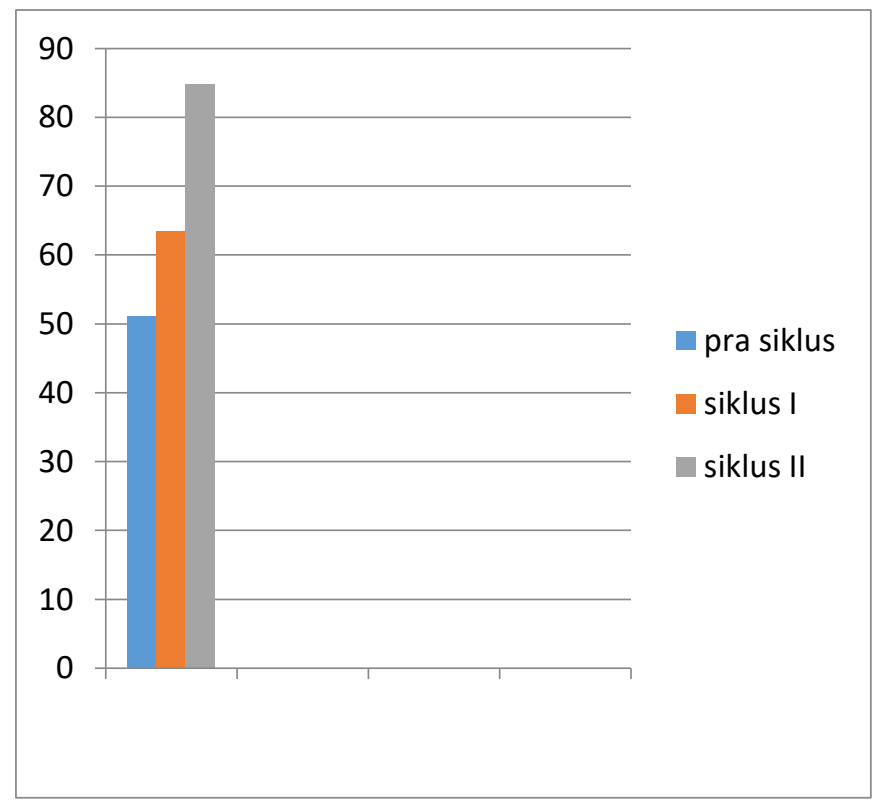

Grafik peningkatan kemampuan mengenal huuf vokal

Kemampuan mengenal huruf vokal dapat ditingkatkan melalui kegiatan bermain gardu kasur. Hal ini disebabkan semua aktivitas anak usia dini selalu berhubungan dengan kegiatan bermain. Bermain adalah kegiatan pokok bagi anak. Bermain akan membuat semua kegiatan yang dilakukan anak terasa menyenangkan. Melalui bermain secara tidak langsung terjadi pembelajaran pada anak. Sejalan dengan pendapat (Özdoğan, 2011), yang menyatakan bahwa bermain tidak hanya digunakan untuk membuat kegiatan menjadi menyenangkan. Ini mencakup proses logis dan membantu anak-anak mengonfigurasi peristiwa, hubungan, dan koneksi. Sebuah permainan mencakup termasuk berpikir, memproduksi, kreativitas, menemukan proses, sangat berarti.

Didukung oleh pendapat(Lockhart, 2010) yaitu kita sebagai pendidik dipercayakan dengan tanggung jawab untuk sepenuhnya melibatkan pikiran dan tubuh anak dengan cara mereka belajar dengan baik. Dengan memahami pentingnya bermain, bagaimana hal itu membantu mengembangkan aspek perkembangan anak, dan aspek tersebut bisa menjadi lebih efektif, memiliki tujuan dan lebih intens dalam interaksi dengan anak-anak selama bermain. 
Dari pendapat diatas memperkuat hasil penelitian yang dilakukan oleh peneliti meningkatkan kemampuan mengenal huruf melalui kegiatan bermain gardu kasur. Kegiatan bermain gardu kasur adalah kegiatan yang dilakukan di dalam ruangan dan dilakukan secara bergantian dan perlombaan. . Sebelum kegiatan bermain gardu kasur, anak-anak diperkenalkan terlebih dahulu dengan tema dan sub tema pembelajaran yang digunakan yaitu tema kebutuhan dan sub tema makanan pokok. Kemudian anak diperkenalkan dengan berbagai macam gambar makanan pokok, bagaimana manfaat makanan pokok, cara mengolah makanan pokok dan mengenal huruf dari kata macam macam makanan pokok. Setelah itu kegiatan bermain gardu kasur dilakukan di secara bergantian masing masing dua anak. Dalam kegiatan bermain gardu kasur membuktikan bahwa anak lebih mampu mengembangkan daya ingatnya. Anak mampu memilih huruf vokal sesuai sub sub tema, Anak mampu mengidentifikasi kata yang berawalan huruf vokal sesuai sub subtema, dan Anak mampu mengidentifikasi huruf vokal yang ada pada kata sesuai sub subtema. .Secarakeseluruhan, kemampuan mengenal huruf vokal anak dapat berkembang dengan baik.

\section{KESIMPULAN}

Berdasarkan hasil penelitian yang telah dilakukan, didapat hasil dengan analisis data pra siklus dengan perolehan persentase TCP sebesar $51.07 \%$, pada siklus I sebesar $63.39 \%$ dan pada siklus II menjadi $84.82 \%$. Berada pada kategori berkembang sesuai harapan dan pada penelitian ini 10 anak sudah mencapai pada kategori berkembang sesuai harapan. Hasil yang diperoleh menunjukan TCP kemampuan mengenal huruf vokal anak telah mencapai kriteria yang diharapkan. Berdasarkan data kualitatif, terlihat adanya peningkatan kemampuan mengenal huruf vokal anak usia 5-6 tahun melalui pemberian tindakan berupa kegiatan bermain gardu kasur. Peningkatan kemampuan mengenal huruf vokal anak terlihat ketika Anak mampu memilih huruf vokal sesuai sub sub tema, Anak mampu mengidentifikasi kata yang berawalan huruf vokal sesuai sub subtema, dan Anak mampu mengidentifikasi huruf vokal yang ada pada kata sesuai sub subtema. Dengan demikian pemberian tindakan berupa kegiatan Anak mampu memilih huruf vokal sesuai sub sub tema, Anak mampu mengidentifikasi kata yang berawalan huruf vokal sesuai sub subtema, dan Anak mampu mengidentifikasi huruf vokal yang ada pada kata sesuai sub subtema dapat meningkatkan kemampuan mengenal huruf vokal anak di TK Villa Beta Padang.

\section{DAFTAR PUSTAKA}

Chugani, Shoba Dewey 2009. Anak Yang Cerdas, Anak Yang Bermain, Jakarta: Garamedia Pustaka Utama

handini Myrnawati Crie. (2012). Metodologi Penelitian untuk Pemula. FIP Press.

Latif Mukhtar, dkk. (2013). Orientasi Baru Pendidikan Anak Usia Dini. Kencana. LN, Y. S. (2016). Psikologi Perkembangan Anak \& Remaja. Rosdakarya. Lockhart, S. (2010). Play: An Important Tool for Cognitive Development. 
HighScope Extensions, 24(3), 1-8.

http://membership.highscope.org/app/issues/142.pdf

Mujib, F. dan R. N. (2012). Permainan Edukatif Pendukung Pembelajaran Bahasa Arab (Yogyakarta). Diva Press.

Novitasari Reni, M. Nasirun, D. D. (2019). Belajar Melalui Bermain untuk Pengembangan Kreativitas dan Kognitif Anak Usia Dini. Jurnal Pendidikan Universitas Garut, 4(1), 6-12.

Özdoğan, E. (2011). Play, mathematic and mathematical play in early childhood education. Procedia - Social and Behavioral Sciences, 15, 3118-3120. https://doi.org/10.1016/j.sbspro.2011.04.256

Pudjiati, S. R. . dan masykouri A. (2011). Mengasah Kecerdasan di usia 0-2 Tahun. Dirjen PAUDNI.

Purnama Sigit, Y. S. H. dan H. (2019). Pengembangan Alat dan Permainan Edukatif Anak Usia Dini. Rosdakarya.

S Pendidikan Anak Usia Dini Undiksha, 2(1). https://doi.org/10.23887/paud.v2i1.3533

Susanto ahmad. (2011). Perkembangan anak usia dini. Prenamedia group. Usia Dini, 4(1), 77. https://doi.org/10.31004/obsesi.v4i1.221

Triharso Agung. (2013). Permainan Kreatif dan Edukatif untuk Anak Usia Dini. ANDI.

Wiwik Pratiwi. (2017). Konsep Bermain Pada Anak Usia Dini. Manajemen Pendidikan Islam , 5, 106-117. 